\title{
Perlindungan Hukum Bagi Pekerja Penyandang Disabilitas Ditinjau Dari Undang-Undang Nomor 13 Tahun 2013
}

\author{
Tri Wahyu Kurniawan \\ Program Magister Kenotariatan, Fakultas Hukum Universitas Surabaya
}

\begin{tabular}{l}
\hline \hline Article Info \\
\hline Article history: \\
Received 29 November 2021 \\
Publish 01 Januari 2022 \\
\end{tabular}

Keywords:

Legal Protection

Workers

Persons with Disabilities

\begin{tabular}{l}
\hline Info Artikel \\
\hline Article history: \\
Received 29 November 2021 \\
Publish 01 Januari 2022
\end{tabular}

Corresponding Author:

Fakultas Hukum Universitas Surabaya, Program Magister Kenotariatan Universitas Surabaya

Email: Triwahyukurniawan11@gmail.com

\begin{abstract}
This study aims to determine the form of legal protection against disabled workers with disabilities. This study uses normative research methods with data collection techniques used to solve the problem formulation is by library data obtained based on legislation and literature - literature or official books. Data analysis used is qualitative approach to primary data and secondary data. The result of the research can be concluded that the form of legal protection for workers with disabilities who are harmed by employers by viewing or reviewing Law No.13 Year 2103, in the law has regulated the legal protection for workers with disabilities. Therefore, the need for legal protection is preventive and repressive, by increasing the supervision of the relevant agencies so that the disability workers are not harmed by the employer. And if there has been a dispute then it can be a repressive legal protection, which prioritizes the form of bipartite negotiations, in deliberation and tripartite, mediated by the facilitator. If in such endeavors remain unreachable, either party may make a lawsuit by enclosing minutes of negotiations and being registered with the industrial relations court at the local district court.
\end{abstract}

\begin{tabular}{l}
\hline ABSTRACT \\
Penelitian ini bertujuan untuk mengetahui bentuk perlindungan hukum terhadap \\
pekerja penyandang disabilitas yang dirugikan. Penelitian ini menggunakan \\
metode penelitian normatif dengan teknik pengumpulan data yang digunakan \\
untuk memecahkan rumusan masalah yaitu dengan data kepustakaan yang \\
diperoleh berdasarkan dari perundang - undangan dan literaturr - literatur atau \\
buku - buku resmi. Analisis data yang dipergunakan adalah pendekatan \\
kualitatif terhadap data primer maupun data sekunder. Hasil penelitian dapat \\
disimpulkan bahwa bentuk perlindungan hukum bagi pekerja penyandang \\
disabilitas yang dirugikan oleh pemberi kerja / pengusaha dengan melihat atau \\
meninjau Undang-Undang No.13 Tahun 2103 , di undang-undang tersebut sudah \\
mengatur tentang perlindungan hukum bagi pekerja penyandang disabilitas \\
tersebut. Untuk itu perlunya perlindungan hukum secara preventif dan represif, \\
dengan lebih meningkatkan pengawasan dari dinas terkait agar pekerja \\
disabilitas ini tidak dirugikan oleh pemberi kerja. Dan jika telah terjadi \\
perselisihan maka dapat dilakukan perlindungan hukum secara represif, yang \\
lebih mengutamakan ke bentuk perundingan secara bipartit, secara musyawarah \\
dan tripartit, dengan ditengahi oleh fasiliator. Jika dalam upaya tersebut tetap \\
tidak mencapai kesepakatan, maka salah satu pihak dapat membuat gugatan \\
dengan melampirkan risalah hasil perundingan dan didaftarkan ke pengadilan \\
hubungan industrial di pengadilan negeri setempat.
\end{tabular}

This is an open access article under the Lisensi Creative Commons AtribusiBerbagiSerupa 4.0 Internasional

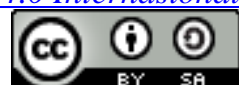

\section{PENDAHULUAN}

Bekerja merupakan salah satu kewajiban setiap orang, sesuai dengan Pasal 28 D ayat (2) Undang-Undang Dasar Negara Republik Indonesia Tahun 1945 (UUD 1945), yang berbunyi bahwa "Setiap orang berhak untuk bekerja serta mendapat imbalan dan perlakuan yang adil dan layak dalam hubungan kerja". Lapangan kerja yang semakin sempit sedangkan jumlah tenaga 
kerja yang semakin banyak menjadikan banyak pengangguran dan bahkan para pekerja bekerja hanya mengikuti kemauan dari para pelaku usaha atau pengusaha.

Problematika ketenagakerjaan sepanjang masa tidak pernah selesai dari masalah perlindungan, pengupahan, kesejahteraan, perselisihan hubungan industrial, pembinaan, dan pengawasan ketenagakerjaan. Hal ini diakibatkan kelemahan pemerintah secara sistematik dalam mengimplementasikan Undang- Undang Ketenagakerjaan, bahkan cenderung ada penyimpangan, hal lain masalah koordinasi dan kinerja antar lembaga pemerintah belum optimal dan masih sangat memprihatinkan.

Perlindungan hukum bagi buruh sangat diperlukan mengingat kedudukannya yang lemah. Disebut oleh Zainal Asikin, yaitu "perlindungan hukum dari kekuasaan majikan terlaksana apabila peraturan perundang-undangan tersebut benar-benar dilaksanakan semua pihak karena keberlakuan hukum tidak dapat diukur secara yuridis saja, tetapi diukur secara sosiologis dan filosofis"

Penyandang disabilitas juga merupakan bagian dalam masyarakat yang juga berhak mendapatkan pekerjaan sesuai dengan tingkat kecacatannya. Perlindungan penyandang dalam dunia kerja pun khususnya sudah dibuatkan peraturan Undang-Undang No 13 Tahun 2003 Pasal 67 sudah dijelaskan bahwa pengusaha yang memperkerjakan penyandang disabilitas wajib memberikan perlindungan yang sesuai dengan tingkat dan kecacatannya meskipun hak penyandang disabilitas sudah diatur dalam pelaksanaan hak-hak para pekerja penyandang disabilitas pun sampai sekarang sering mendapatkan diskriminasi di tempat kerja. Program kebijakan pemerintah bagi penyandang disabilitas cenderung berbasis belas kasih, sehingga kurang memberdayakan penyandang disabilitas untuk terlibat dalam dunia kerja. Kurangnya sosialisasi peraturan perundang-undangan tentang disabilitas menyebabkan perlakuan stakeholder, baik dari unsur pemerintahan dan swasta yang kurang peduli.

Dalam penelitian ini bertujuan untuk membahas mengenai perlindungan hukum bagi pekerja penyandang disabilitas yang hak-haknya tidak terpenuhi dan tentang hak dan kewajiban pekerja penyandang disabilitas dan upaya hukum secara non litigasi bagi pekerja penyandang disabilitas apabila hak-haknya tidak terpenuhi oleh pemberi kerja dan juga upaya hukum secara litigasi bagi pekerja penyandang disabilitas yang hak-haknya tidak dipenuhi.

\section{METODE PENELITIAN}

Jenis Penelitian yang digunakan adalah penelitian hukum normatif. Yang dimaksud dengan normatif atau metode penelitian hukum kepustakaan adalah metode atau cara yang dipergunakan didalam penelitian hukum yang dilakukan dengan cara meneliti bahan pustaka yang Dalam penelitian hukum normatif, data diperoleh langsung dari pihak yang bersangkutan, yaitu berupa perilaku hukum masyarakat yang diteliti secara langsung. Pendekatan yang dipakai adalah pendekatan perundang-undangan (statute approach) merupakan suatu pendekatan yang dilakukan dengan cara menelaah semua peraturan perundang-undangan dan regulasi yang berkaitan dengan permasalahan yang diangkat. Dari sini, maka akan dapat ditemukan konsistensi dan kesesuaian di antara peraturan perundang-undangan tersebut. Selanjutnya, hasil telaahan tersebut digunakan untuk menjawab permasalahan yang diangkat. Sumber bahan hukum dalam penelitian ini menggunakan data primer dan data sekunder. Data primer adalah data yang diperoleh langsung dari sumber pertama. Jadi data primer diperoleh langsung dari lapangan dan diolah oleh peneliti. Sedangkan data sekunder.

Bahan hukum primer merupakan bahan hukum yang bersifat autoritatif artinya mempunyai otoritas. Bahan-bahan hukum primer terdiri dari perundang-undangan, catatan-catatan resmi atau risalah dalam pembuatan perundang-undangan dan putusan-putusan hakim.Dalam hal ini peenulis menggunakan Undang-Undang No. 13 Tahun 2003 tentang Ketenagakerjaan, UndangUndang Penyandang Cacat.

Bahan hukum sekunder adalah semua publikasi tentang hukum yang bukan merupakan dokumen yang resmi.Publikasi tersebut terdiri atas: yang pertama, buku-buku teks yang membicarakan suatu dan/atau beberapa permasalahan hukum termasuk skripsi, tesis, dan 
disertasi hukum, kedua yaitu kamus-kamus hukum ,yang ketiga yaitu jurnal-jurnal hukum, dan yang keempat yaitu komentar-komentar atas putusan hakim. Publikasi tersebut merupakan petunjuk atau penjelasan mengenai bahan hukum primer atau bahan hukum sekunder yang berasal dari kamus, ensiklopedia, jurnal, surat kabar, dan sebagainya. Bahan hukum tersier adalah petunjuk atau penjelasan mengenai bahan hukum primer atau bahan hukum sekunder yang berasal dari kamus, ensiklopedia, majalah dan sebagainya.

Untuk memperoleh data yang diperlukan dalam suatu penelitian, lazimnya dikenal dengan beberapa jenis alat pengumpul data, yaitu:

a. Studi dokumen merupakan langkah awal dari setiap penelitian hukum (baik normatif maupun sosiologis). Studi kepustakaan diperlukan sebagai landasan dalam menganalisis suatu permasalahan serta mampu memberikan solusi terhadap permasalahan tersebut terkait dengan fenomena yang ada dengan teori hukum yang ditetapkan.

b. Wawancara yang dilakukan oleh penulis bertujuan untuk mendapatkan informasi terkait permasalahan yang diambil oleh penulis sebagai bahan penelitian yang bersumber dari informan terkait dengan permasalahan yang diambil oleh penulis. Adapun dalam prakteknya penulis melakukan wawancara langsung kepada pekerja maupun pemberi kerja yang pernah terlibat didalam permasalahan yang terjadi.

c. Observasi atau data lapangan yang diperlukan sebagai data penunjang dalam penelitian ini, penulis memperoleh dari pihak-pihak terkait yang berada diruang lingkup kerja antara pekerja dengan pemberi kerja.

Tahap berikutnya setelah pengumpulan data selesai adalah metode analisis data Langkah pengumpulan data dalam tulisan ini adalah melalui studi kepustakaan yaitu diawali dengan inventarisasi semuah data yang terkait dengan pokok permasalahan, kemudian diadakan klasifikasi data yang terkait dan selanjutnya data tersebut disusun dengan sistematika untuk lebih mudah membaca dan mempelajarinya.

Langkah pembahasan dilakukan dengan menggunakan penalaran bersifat deduktif dalam arti berawal dari pengetahuan hukum yang bersifat umum yang diperoleh dari peraturan perundang-undangan, literature danberkas perkara yang kemudian dipakai sebagai bahan analisis terhadap permasalahan yang dikemukakan sehingga diperoleh jawaban dari permasalahan yang bersifat khusus. Pembahasan selanjutnya digunakan penafsiran sistematis dalam arti mengkaitkan pengertian antara peraturan perundangan-undangan yang ada serta pendapat para sarjana.

\section{HASIL PENELITIAN DAN PEMBAHASAN}

Pengertian hak adalah suatu kewenangan atau kekuasaan yang diberikan oleh hukum, baik pribadi maupun umum. Dapat diartikan bahwa hak adalah sesuatu yang patut atau layak diterima.

Macam-macam hak tenaga kerja dan hak atas pekerjaan merupakan hak asasi manusia ,karena :

a. Kerja melekat pada tubuh manusia. Kerja adalah aktifitas tubuh dan karena itu tidak bisa dilepaskan atau difikirkan lepas dari tubuh manusia;

b. Kerja merupakan perwujudan diri manusia, melalui kerja manusia merealisasikan dirinya sebagai manusia dan sekaligus membangun hidup dan lingkungannya yang lebih manusiawi. Maka melalui kerja manusia menentukan hidupnya sendiri sebagai manusia yang mandiri;

c. Hak atas kerja juga merupakan salah satu hak asasi manusia karena kerja berkaitan dengan hak atas hidup, bahkan hak atas hidup yang layak.

Penyandang cacat diberi kesamaan kesempatan dengan manusia normal lainnya. Kesamaan kesempatan adalah keadaan yang memberi peluang kepada penyandang cacat untuk mendapatkan kesempatan dalam aspek kehidupan dan penghidupan. Pasal 5 Undang-Undang Nomor 8 Tahun 2016 tentang Penyandang cacat menegaskan bahwa setiap penyandang cacat untuk mendapatkan hak dan kesempatan yang sama dalam aspek dalam segala aspek kehidupan dan penghidupan. Untuk itu, setiap penyandang cacat berhak memperoleh :

a. Hidup; 
b. Bebas dari stigma;

c. Privasi;

d. Keadilan dan perlindungan hukum;

e. Pendidikan;

f. Pekerjaan, kewirausahaan, dan koperasi;

g. Kesehatan;

h. Politik;

i. Keagamaan;

j. Keolahragaan;

k. Kebudayaan dan pariwisata;

1. Kesejahteraan sosial;

m. Aksebilitas;

n. Pelayanan publik;

o. Perlindungan dari bencana;

p. Habilitasi dan rehabilitasi;

q. Konsensi;

r. Pendataan;

s. Hidup secara mandiri dan dilibatkan dalam masyarakat;

t. Berekspresi, berkomunikasi, dan memperoleh informasi;

u. Berpindah tempat dan kewarganegaraan;

v. Bebas dari tindakan diskriminasi, penelantaran, penyiksaan, dan eksploitasi.

Pasal ini merupakan penegasan hak dan kesempatan yang sama bagi penyandang cacat, sebagaimana yang dimaksud dalam Pasal 5. Selanjutnya didalam Pasal 14 menegaskan bahwa perusahaan-perusahaan, baik merupakan perusahaan Negara maupun swasta, diharuskan memberikan kesempatan dan perlakuan yang sama kepada penyandang cacat dengan memperkerjakan penyandang cacat di perusahaannya, sesuai dengan jenis dan derajat kecacatan, pendidikan, dan kemampuannya, yang jumlahnya disesuaikan dengan jumlah karyawan dan atau kualifikasi perusahaan. Termasuk dalam kategori perusahaan negara meliputi : BUMD (Badan Usaha Milik Daerah) maupun BUMN (Badan Usaha Milik Negara), sedangkan perusahaan swasta termasuk di dalamnya koperasi, perusahaan wajib untuk memperkerjakan sekurang-kurangnya satu orang penyandang cacat yang bersangkutan, untuk setiap 100 karyawan, sedangkan bagi perusahaan yang menggunakan teknologi tinggi harus memperkerjakan sekurang-kurangnya $2 \%$ penyandang cacat yang memenuhi persyaratan dan kualifikasi pekerjaan yang bersangkutan, walaupun jumlah karyawannya kurang dari 100.

Hak-hak pekerja Disabilitas diatur dalam Pasal 11 Undang-Undang No.8 Tahun 2016 Tentang Penyandang disabilitas adalah sebagai berikut :

a. Memperoleh pekerjaan yang diselenggarakan oleh pemerintah, pemerintah daerah, atau swasta tanpa diskriminasi;

b. Memperoleh upah yang sama dengan tenaga kerja yang bukan disabilitas dalam jenis pekerjaan dan tanggung jawab yang sama;

c. Memperoleh akomodasi yang layak dalam pekerjaan;

d. Tidak diberhentikan dengan alasan disabilitas;

e. Mendapatkan program kembali bekerja;

f. Penempatan kerja yang adil, proporsional, dan bermartabat;

g. Memperoleh kesempatan dalam mengembangkan jenjang karir serta segala hak normatif yang melekat di dalamnya;

h. Memajukan usaha, memiliki pekerjaan sendiri, wiraswasta, pengembangan koperasi dan memulai usaha sendiri.

Jika dibandingkan dengan Undang-Undang No.13 Tahun 2003 Tentang ketenagakerjaan, hak pekerja normal dengan hak-hak pekerja penyandang disabilitas bisa dikatakan hampir sama, karena di penjelasan Pasal 5 Undang-Undang Ketenagakerjaan menyatakan bahwa “ Setiap tenaga kerja mempunyai hak yang sama untuk memperoleh pekerjaan dan penghidupan 
yang layak tanpa membedakan kelamin, suku, ras, agama, aliran politik sesuai dengan minat dan kemampuan tenaga kerja yang bersangkutan, termasuk perlakuan yang sama terhadap para penyandang cacat “. Hanya saja pemberi kerja/pengusaha harus memberikan perlindungan yang sesuai dengan jenis dan derajat kecacatannya.

Banyak pandangan negatif dari masyarakat bahwa penyandang cacat dipandang dari aspek kecacatan dan kelemahannya. Para penyandang cacat diyakini sebagai orang lemah, tidak bisa bekerja,tidak bisa berbuat apa-apa sehingga tidak bisa ditolong lagi untuk menjadi orang yang berpotensi dan mandiri. Parang penyandang cacat dianggap bahwa hanya menggantungkan belas kasihan orang lain. Kelemahan yang dimiliki para penyandang cacat seperti adanya sikap mental sosial psikologis yang mudah menyerah, sering mengisolir diri, dan aspek kelemahan lain yang dimilikinya akan menyulitkan penempatan kerja diperusahaan-perusahaan yang membutuhkan.

Hak-hak pemberi kerja/pengusaha sebagai berikut :

a. Berhak sepenuhnya atas hasil kerja pekerja;

b. Berhak atas ditaatinya aturan kerja oleh pekerja termasuk pemberian sanksi;

c. Berhak atas perlakuan yang hormat dari pekerja;

d. Berhak melaksanakan tata tertib kerja yang dibuat oleh pengusaha;

Hubungan antar pemberi kerja dan buruh lahir dari sebuah perikatan yaitu perjanjian kerja, pada prinsipnya hubungan kerja terjalin dari pembuatan perjanjian kerja karena merupakan titik tolak adanya suatu hubungan kerja. Kewajiban buruh melakukan pekerjaan pada atau dibawah pimpinan majikan, yang sekaligus merupakan hak majikan atas pekerjaan dari buruh tersebut.

Pengertian kewajiban adalah suatu beban atau tanggungan yang bersifat kontraktual, dengan kata lain kewajiban adalah sesuatu yang harus diberikan atau dipertanggungjawabkan. Kewajiban pekerja penyandang disabilitas dan pekerja lainnya semuanya sama. Berikut adalah kewajiban pekerja :

a. Wajib melakukan prestasi/pekerjaan bagi majikan;

b. Wajib mematuhi peraturan perusahaan;

c. Wajib mematuhi perjanjian kerja;

d. Wajib mematuhi perjanjian perburuhan;

e. Wajib menjaga rahasia perusahaan;

f. Wajib mematuhi peraturan dari pemberi kerja;

g. Wajib memenuhi segala kewajiban selama izin belum diberikan dalam hal ada banding yang belum ada putusannya;

h. Memberikan keterangan yang benar apabila diminta oleh pengawas atau ahli keselamatan dan kesehatan kerja (K3);

i. Memakai alat pelindung diri yang diwajibkan. Memenuhi dan menaati persyaratan keselamatan dan kesehatan kerja (K3) yang berlaku ditempat kerja yang bersangkutan;

j. Wajib memberikan pelatihan atau pembinaan kepada pekerja.

Para penyandang disabilitas ini masih banyak mendapatkan perlakuan diskriminasi dan kurangnya kepedulian yang mengakibatkan kerugian kepada penyandang disabilitas. Hal ini tidak saja di perusahaan saja, tetapi di intansi pemerintahan juga seperti itu. Mereka memberikan persyaratan berupa sehat jasmani maupun rohani. Hal tersebut menjadi persepsi kepada masyarakat bahwa penyandang disabilitas tidak bisa memberikan kontribusi yang baik di perusahaan maupun di instansi pemerintahan.

Semua tidak luput dari lemahnya pengawasan yang dilakukan oleh instansi pemerintah terkait. Bahwa sepatutnya pegawai pengawas dinas tenaga kerja mengawasi bagaimana kepatutan perusahaan dalam memberikan peluang kerja kepada penyandang cacat. Tidak hanya diskrimanasi saja, tetapi tenaga kerja penyandang disabilitas ini juga masih banyak hak-haknya yang belum terpenuhi, seperti pekerja disabilitas yang mendapatkan upah tidak sama dengan pekerja non disabilitas.

Menurut Undang-Undang No.8 Tahun 2016 tentang penyandang cacat, penyandang cacat adalah setiap orang yang mempunyai kelainan fisik ataupun mental, yang dapat menganggu 
atau merupakan rintangan dan hambatan baginya untuk melakukan secara selayaknya, yang terdiri dari:

a. Penyandang Disabilitas Fisik;

b. Penyandang Disabilitas Intelektual;

c. Penyandang Disabilitas Mental;

d. Penyandang Disabilitas Sensorik;

Tentang Hak Asasi Manusia (HAM) yang memberikan perlindungan terhadap tenaga kerja yang cacat adalah sebagai berikut:

a. Pasal 41 ayat 2 : setiap penyandang cacat, orang yang berusia lanjut, wanita hamil, dan anak-anak, berhak memperoleh kemudahan dan perlakuan khusus;

b. Pasal 42 : setiap warga Negara yang berusia lanjut, cacat fisik dan atau cacat mental berhak memperoleh perawatan, pendidikan, pelatihan, dan bantuan khusus atau biaya Negara, untuk menjamin kehidupan yang layak sesuai dengan martabat kemanusiaanya, meningkatkan rasa percaya diri dan kemampuan berpartisipasi dalam kehidupan bermasyarakat, berbangsa dan bernegara.

Bentuk perlindungan hukum secara Preventif merupakan pencegahan agar pekerja disabilitas ini. Jika dilihat menurut UU Ketenagakerjaan dan UU Penyandang Disabilitas, dapat dilihat bentuk pencegahan dalam perlindungan pekerja adalah dengan melihat $\backslash$ aspek:

1. Kontrak Kerja

Pemberi kerja memberikan kontrak kerja kepada tenaga kerja disabilitas dengan kontrak kerja yang sama dengan tenaga kerja non disabilitas. Karena tidak ada aturan khusus kontrak bagi pekerja disabilitas yang membedakan dengan pekerja lainnya, namun ada aspek yang perlu diperhatikan dalam perjanjian kerja dengan pekerja disabilitas yang sesuai dengan jenis dan derajat kecacatannya.terdapat dalam Pasal 5 Undang-undang No.13 tahun 2003 tentang ketenagakerjaan bahwa setiap tenaga kerja memiliki kesempatan yang sama tanpa adanya diskriminasi untuk memperoleh pekerjaan.

2. Kesehatan dan Keselamatan Kerja

Pada Pasal 86 ayat (1) UU Ketenagakerjaan menjelaskan bahwa setiap pekerja/buruh mempunyai hak untuk memperoleh perlindungan atas keselamatan dan kesehatan kerja, moral dan kesusilaan kerja, perlakuan yang sesuai dengan harkat dan martabat manusia serta nilai-nilai agama.seharusnya pemberi kerja melampirkan mengenai kesehatan dan keselamatan pekerja pada perjanjian kerja yang didapat saat melakukan pekerjaan yang diberikan pemberi kerja.

Upaya represif yang dapat diupayakan oleh pekerja penyandang disabilitas adalah dengan melihat hak-hak atas pekerjaan terdapat pada pasal 11 UU Penyandang Disabilitas yang menyatakan bahwa penyandang disabilitas berhak memperoleh pekerjaan yang diselenggarakan oleh Pemerintah ataupun Swasta tanpa diskriminasi serta memperoleh upah yang sama dalam jenis pekerjaan dan tanggung jawab yang sama serta tidak di berhentikan dari pekerjaaanya dengan alasan disabilitas, apabila pengusaha menghalang-halangi/ melarang hak penyandang disabilitas,maka dapat dilakukannya bentuk perlindungan hukum represifnya. Perselisihan hak adalah perselisiahn yang timbul karena tidak dipenuhinya hak, akibat adanya perbedaan pelaksanaan atau penafsiran terhadap ketentuan peraturan perundang-undangan, perjanjian kerja, peraturan perusahaan, atau perjanjian kerja sama.

Menurut Pasal 3 UU PPHI mewajibkan setiap perselisihan hubungan industrial yang terjadi harus diselesaikan terlebih dahulu melalui perundingan bipartit, yang dimana lebih mengutamakan secara musyawarah dan mencapai mufakat bersama dalam suatu perselisihan, untuk menghindari perundingan tripartit yang dapat memperpanjang perselisihan dalam hubungan industrial antara pekerja dengan pemberi kerja.

Proses perundingan bipartit ini harus dihadiri oleh masing-masing pihak yaitu pemberi kerja dan pekerja. Pihak pekerja harian lepas diharuskan melakukan proses perundingan ini terlebih dahulu dengan pihak pemberi kerja. Karena dengan melalui proses ini masing-masing pihak dapat memperoleh hasil yang sesuai dan dapat menekan biaya serta 
menghemat waktu dari masing-masing pihak. Perlindungan melalui bipartit harus dapat diselesaikan para pihak dalam jangka waktu 30 hari uang dihitung dari dilakukannya perundingan oleh para pihak. Jika dalam jangka waktu 30 hari salah satu pihak menolak untuk berunding dan tidak dapat mencapai kesapakatan, maka perundingan secara bipartite dinyatakan gagal.

Perundingan tripartit merupakan perundingan antara pekerja dengan pemberi kerja yang melibatkan pihak ketiga sebagai fasiliator dalam penyelesaian perselisihan hubungan industrial diantara pekerja dan pemberi kerja. Perundingan tripartit bisa melalui mediasi, konsiliasi dan arbitrase. Perundingan tripartit harus dihadiri oleh pihak-pihak yang bersangkutan seperti pekerja dengan pemberi kerja dan dengan dihadiri fasiliator yang disediakan oleh Dinas Ketenagakerjaan berupa mediator, konsiliator atau arbiter tergantung perselisihan yang sedang terjadi.

Penyelesaian melalui mediasi, konsiliasi atau arbitrase didalam perundingan tripartit tentunya sama, hanya berbeda mengenai pokok perselisihan yang diatasi dan diselesaiakan. Dalam perselisihan mengenai pekerja penyandang disabilitas ini tidak perlu sampai masuk kedalam upaya perlindungan hukum melalui pengadilan hubungan industrial. Karena bisa diselesaikan dengan proses perundingan bipartit atau tripartit.

\section{KESIMPULAN}

Sesuai dengan pembahasan dan penelitian serta data yang telah dikumpulkan dalam jurnal ini maka didapatkan beberapa kesimpulan sebagai berikut :

a. Perlindungan hukum yang dapat diterapkan dan dilakukan terhadap pekerja penyandang disabilitas yang tidak terpenuhinya hak-haknya adalah perlindungan hukum secara preventif dan represif. Perlindungan hukum secara preventif yang dapat dilakukan pekerja penyandang disabilitas adalah dengan melihat Pasal 5 Undang-Undang No.13 Tahun 2003 tentang ketenagakerjaan menyatakan, bahwa setiap setiap tenaga kerja mempunyai hak dan kesempatan yang sama untuk memperoleh pekerjaan dan penghidupan yang layak tanpa membedakan jenis kelamin,suku,ras agama, aliran politik sesuai dengan minat kemampuan tenaga kerja yang bersangkutan. Pasal 67 Undang-Undang No.13 Tahun 2003 menyatakan bahwa pengusaha yang memperkerjakan tenaga kerja penyandang cacat wajib memberikan perlindungan sesuai dengan jenis dan derajat kecacatannya. Perlindungan hukum secara represif yang dapat dilakukan pekerja penyandang disabilitas yang tidak mendapatkan haknya dan mendapatkan kerugian adalah dengan melakukan perundingan bipartit dan perundingan tripartit.

b. Perundingan bipartit adalah perundingan yang melakukan pendekatan terlebih dahulu secara bermusyawarah dengan pemberi kerja dan mencapai kesepakatan bersama. Tetepi jika tidak tercapai kesepakatan maka dapat dihadirkan pihak ketiga yang disediakan oleh dinas yang berwenang dan bertanggung jawab. Sebagai penengah dalam penyelesaian perselisihan hubungan industrial tersebut, atau bisa disebut perundingan tripartit. Jika didalam perundingan bipartit dan perundingan tripartit tidak mencapai kesepakatan antara pekerja dengan pemberi kerja, maka dapat dilakukan upaya hukum secara litigasi melalui pengadilan hubungan industrial di pengadilan negeri setempat. Dengan salah satu pihak membuat gugatan dan mengajukan gugatan tersebut ke pengadilan dengan melampirkan hasil risalah bahwa telah dilakukan perundingan dan gagal. Tata cara dan syarat-syarat gugatan ke pengadilan hubungan industrial baik mengenai perselisihan hak, perselisihan kepentingan, perselisihan pemutusan hubungan kerja maupun perselisihan antar serikat pekerja dalam satu perusahaan menurut UU PPHI adalah sama, yaitu harus melalui proses mediasi, konsiliasi atau arbitrase terlebih dahulu berhubung dalam pengajuan gugatan tersebut wajib dilampiri risalah penyelesaian melalui mediasi, konsiliasi dan arbitrase. Bila tidak, hakim wajib mengembalikan gugatan tersebut pada penggugat. Gugatan meliputi tingkat pekerja/buruh bekerja atau tempat perusahaan berada. 


\section{DAFTAR PUSTAKA}

Buku

Agusmidah. Dinamika Dan Kajian Teori. (Bogor: Ghalia Indonesia, 2012).

Wijayanti, Asri. Hukum Ketenagakerjaan Pasca Reformasi, (Jakarta: Sinar Grafika, 2013).

Marzuki, Peter Mahmud. Penelitian Hukum, (Jakarta: Kencana, 2006).

Sutedi, Adrian. Hukum Perburuhan, (Jakarta: Sinar Grafika, 2011).

Setiawan, Wijayanto. Pengadilan Perburuhan Di Indonesia, (Sidoarjo: Laros, 2007).

Asikin, Zainal. Dasar-dasar Hukum Perburuhan, (Jakarta: Raja Grafindo Persada, 1993).

Zainuddin, Ali. Metode Penelitian Hukum, (Jakarta: Sinar Grafika, 2014).

Peraturan Perundang-Undangan

Undang-Undang Nomor 39 Tahun 1999 Tentang Hak Asasi Manusia.

Undang-Undang Nomor 13 Tahun 2003 Tentang Ketenagakerjaan.

Undang-Undang Nomor 8 Tahun 2016 Tentang Disabilitas. 